\title{
PREDICTIVE IMPORTANCE OF MORPHOMETRIC ANALYSIS OF TRIPLE-NEGATIVE BREAST CANCER
}

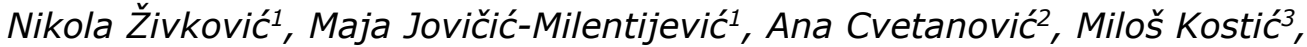 \\ Miodrag Djordjević4 , Dane Krtinićs
}

\begin{abstract}
Triple-negative breast cancers denote malignant epithelial tumors showing complete hormonal independence with negative HER2 expression. Histologically, in most cases these are high-grade tumors, showing fields of central necrosis, lymphocytic infiltration, and fibrosis. The aim of the study was to examine morphometric parameters related to nuclear size depending on the type of carcinoma, as well as tumor proliferation. The entire research was conducted at the Center for Pathology and Pathological Anatomy, Clinical Center Niš. Sixty-four biopsy samples of triple-negative breast cancers were analysed, including 40 ductal, 6 lobular, 6 medullary, 4 ductulolobular, 4 metaplastic, 2 adenoid cystic and 2 apocrine carcinomas. The morphometric analysis was performed in the software package "ImageJ" version 1.52a. The statistical analysis of data was done in the software package SPSS 15.0. By comparing the values of the studied morphometric parameters, statistically significantly higher parameter values for Area, Perim and Feret were found in the group of medullary carcinomas, as well as the parameters for Integrated Optical Density. The value of integrated optical density was also very high in the ductal carcinoma group, but with no statistically significant differences due to high standard deviation. Metaplastic carcinoma showed the highest proliferative activity. Numerous similar studies have been trying to identify a specific marker of these carcinomas, which is still a challenge due to its aggressiveness. These are high-grade tumors with a broad spectrum of polymorphisms, usually with an overlapping morphological presentation, therefore, additional analyses are required in order to set adequate diagnosis.
\end{abstract}

Acta Medica Medianae 2020;59(2):38-46.

Key words: triple-negative breast cancer, immunohistochemistry, morphometry

\footnotetext{
${ }^{1}$ University of Niš, Faculty of Medicine, Department of Pathology, Niš, Serbia

${ }^{2}$ University of Niš, Faculty of Medicine, Department of Oncology, Niš, Serbia

${ }^{3}$ University of Niš, Faculty of Medicine, Department of Immunology, Niš, Serbia

${ }^{4}$ University of Niš, Faculty of Medicine, Department of Surgery, Niš, Serbia

${ }^{5}$ University of Niš, Faculty of Medicine, Department of Pharmacology and Toxicology, Niš, Serbia
}

Contact: Nikola Živković

81 Dr. Zoran Djindjić Blvd., 18000 Niš, Serbia

E-mail: nikola.zivkovic@medfak.ni.ac.rs

\section{Introduction}

Breast cancer is characterised by a wide range of morphological characteristics, unpredictable biological behaviour, various forms of presentation, sometimes unclear clinical evolution and generally good response to therapy. According to the data of the American Cancer Society (ACS), as many as $25 \%$ of all cancers detected in women are breast cancers, accounting for about 1.5 million newly discovered cases on a global level, per annum. So far, the disease has been considered a disease of the modern world, but nearly $50 \%$ of cancers, with a mortality rate of around $58 \%$, are detected in underdeveloped and developing countries. Given the insidious clinical course, most of them are detected in late stages of development when therapeutic options are limited, which results in low survival rates. In recent years, however, especially in developed countries, there has been a slight decline in the mortality rate owing to the coordinated work of the health service at all levels of health care and the acceptance of breast cancer as one of the key global health problems of today (1).

Considering the heterogeneity of breast cancer as a disease, major subtypes and classifications can be based on histopathological features, tumor grade, stage, receptor status, and gene expression (2).

Depending on whether there is a puncture of the basal membrane or not, all carcinomas can be divided into noninvasive (ductal and lobular carci- 
noma in situ) and invasive where, due to the membrane puncture, we encounter stromal infiltration with the possibility of metastasis (invasive ductal carcinoma, invasive lobular carcinoma, medullary, colloid or mucinous, tubular carcinoma, etc.).

The histologic grading of breast cancer is nowadays commonly done by using the so-called Nottingham modification (Elston-Ellis) of the BloomRichardson grading system, in which the degree of tubule formation, nuclear polymorphism, and mitotic activity are taken into account for the assessment. Based on these criteria, both nuclear and histological, all carcinomas can be divided into 3 grades as well (Grade 1, Score 3 and 4), which deviate from normal cells the least, moderately (Grade 2, Score 5, 6 and 7) and poorly (Grade 3, Score 8 and 9) differentiated, which show the highest degree of polymorphism. Tumor grading is important not only because it can provide prognostic information, but because it is also a factor which decides on the therapeutic approach $(3,4)$.

First of all, from a clinical point of view, the TNM classification is very important. It is based on the assessment of tumor size and the degree of its invasion of surrounding breast tissue $(T)$, the degree of involvement of regional lymph nodes $(\mathrm{N})$, and the presence or absence of distant metastases (M), providing information that enables determining the stage of a tumor disease. When $\mathrm{T}, \mathrm{N}$ and $\mathrm{M}$ are determined, the corresponding stage 0, I, II, III or IV is assigned $(5,6)$.

Local-regional recurrence of the disease has been described as ipsilateral, in the breast itself after lumpectomy, on the chest wall after mastectomy, or recurrent in the ipsilateral axilla, or supraclavicular lymph nodes (much less frequently in infraclavicular and intramammary lymph nodes). About $10-15 \%$ of patients with stage I and II tumor disease will develop recurrent disease after breast-conserving surgery and radiation therapy, while $10-20 \%$ of patients with stage I-IIIA will develop recurrent chest disease after mastectomy. Several factors are related to the biological behaviour of breast cancer, as well as to local-regional recurrence. They most commonly include lymphovascular invasion, younger patients, tumor growth rate, tumor margin resection status (tumor distance from the nearest resection margin), positive nodal status, high tumor grade, extensive in situ component, tumor multifocality and multicentricity, hormone-independent tumors, poor response to adjuvant therapy (7-10).

Defining biological characteristics of breast cancer can be facilitated by the characterization of different histologic types of tumors, understanding of the disease prognosis and the systemic therapy plan. The immunohistochemical analysis of protein expression in carcinoma cells is nowadays routinely used. Considering a wide range of immunohistochemical markers, ER, PR, HER2, and Ki67 have certainly seen the greatest use in prognosis and prediction.

Tumors that show expression of estrogen and progesterone receptors are referred to as hormonedependent tumors. A positive immunohistochemical reaction is used to interpret nuclear expression. About $80 \%$ of all breast tumors are ER+, and about $65 \%$ are $\mathrm{PR}+(11)$. The importance of determining these receptors is seen in the choice of therapy, which, in case of their expression, specifically targets these antigens, i.e. hormone therapy, but also that tumors that are hormone-independent are very often of higher grade, with a significantly worse prognosis. Numerous genetic studies have identified a certain association between the overexpression of the HER2 oncogene which belongs to the group of epidermal growth factors and its product in the form of a transmembrane protein, and high-grade tumors that exhibit expansive and aggressive growth. Its overexpression occurs in 15-20\% of breast cancer cases $(12,13)$. Numerous clinical studies have shown that tumors labelled as HER2+ tumors are high-grade tumors of high metastatic potential and poor prognosis. Ki67 is another marker that, if high, indicates a worse prognosis, and a high degree of malignant cell division. Considering these biological markers, that is, the presence or absence of ER and PR receptors, as well as HER2 overexpression, the following subtypes have been identified:

1. Luminal A (ER+ and/or PR+, HER2-, low Ki-67 proliferative index level). These tumors are lower-grade tumors (1 and 2), generally showing a slow growth tendency, indolent flow, and are less aggressive than other subtypes. They are characterised by the best prognosis and the best response to therapy. This group includes ductal invasive (no special type-NST), classic lobular invasive, tubular, cribriform, mucinous and neuroendocrine tumor. A cut-off value of $20 \%$ is used to estimate the height of the Ki67 proliferative index.

2. Luminal B (ER+ and/or PR+, HER2-/+ and high Ki-67 proliferative index level). This tumor group includes higher-grade carcinomas (2 and 3), with more aggressive and faster growth rates than Luminal A, with more frequent metastases in regional lymph nodes, as well as with more frequent recurrences.

3. HER2 positive non-luminal type (ER-, PRand HER2+). Although these are highly aggressive tumors (mostly grade 3 ) with a high incidence of distant metastases, targeted Trastuzumab therapy has made significant progress in the therapeutic approach.

4. Triple-negative (ER-, PR-, HER2-). Despite their simple definition, from a morphological, genetic and clinical point of view, they are the most heterogeneous category of breast cancer. The most common is invasive ductal carcinoma (NST), followed by metaplastic carcinoma, carcinoma with medullary characteristics (medullary carcinoma), carcinoma with apocrine characteristics (apocrine carcinoma), secretory carcinoma and adenoid cystic carcinoma. Gene expression profiling has enabled the division of this group of tumors into different, prognostically essential subgroups: basal-like 1 (BL1), basal-like 2 (BL2), immunomodulatory (IM), mesenchymal (M), mesenchymal stem-like (MSL), and luminal androgen receptor (LAR). BL1 breast cancer is most commonly invasive ductal NST with a 
high Ki67 proliferative index and basal cytokeratin gene expression (CK5/6, CK14, CK17). BL2 tumors are also most commonly manifested as invasive ductal carcinomas of NST with basal cytokeratin expression, TP63, and growth factor signalling (EGF and IGFR1 pathways). The immunomodulatory subtype overlaps with carcinoma with medullary features containing rich lymphocytic infiltrate. Mesenchymal and mesenchymal stem-like subtypes are clinically and morphologically presented as metaplastic carcinoma characterized by both epithelial and mesenchymal differentiation. These are tumors enriched with genes important for the cell cycle and signal pathways of the growth factor. The LAR subtype is presented as carcinoma with apocrine differentiation which correlates with a molecular apocrine type. This carcinoma is characterized by luminal cytokeratin expression as well as the expression of androgen receptors and mRNA, which further explains their hormonal dependence $(7,14-19)$.

\section{The aim}

The aim of the study was to examine morphometric parameters of triple-negative breast cancers, related to nuclear size depending on the type of carcinoma, as well as tumor proliferation.

\section{Materials and methods}

The entire study was conducted at the Center of Pathology and Pathological Anatomy, Clinical Center Niš. The analysed material included tissue obtained by surgery and biopsy procedure of breast tumors from the Clinic of Surgery of the Clinical Center in Niš. All analysed patients were female. After the intervention, the tissue was fixed in $10 \%$ formalin for at least 24 hours. The microscopic analysis of the obtained preparations, stained with the standard hematoxylin-eosin method, set basic diagnostics. At the same time, a representative sample was determined, i.e. tumor field area with minimal necrosis fields and inflammatory infiltrate on which immunohistochemical staining was performed. Considering the high polymorphism of breast cancer, another of the parameters for the selection of the sample was the most polymorphic image on the histopathological preparation. Healthy breast tissue served as a positive, internal control. Ductal epithelial cells showed positive ER and PR expression, i.e. negative HER2 expression.

Sixty-four biopsy samples of triple-negative breast cancers were analysed, including 40 ductal, 6 lobular, 6 medullary, 4 ductulolobular, 4 metaplastic, 2 adenoid cystic and 2 apocrine carcinomas.

\section{Immunohistochemical analysis}

Within the standard analysis of steroid receptors, as well as HER2 oncoproteins, a group of triplenegative cancers was separated. The expression of $\mathrm{Ki} 67$, a marker of tumor proliferation, was analysed.

Immunohistochemical staining was performed on samples up to $5 \mu \mathrm{m}$ of thickness obtained from paraffin blocks. The representative sample was taken for analysis and the following antibodies were used: anti-ER (EP1, ready to use; DAKO, Glostrup, Denmark), anti-PgR (PgR636, ready to use; DAKO, Glostrup, Denmark), anti-HER -2 (HercepTest ${ }^{\mathrm{TM}}$, DAKO, Glostrup, Denmark) and anti-Ki67 (MiB-1, ready to use; DAKO, Glostrup, Denmark).

Nuclear staining for estrogen and progesterone is considered a positive reaction. Adequate scoring was performed, relative to the intensity ( 0 3) and area (0-5) of the expression in the tumor tissue. Overall, a score of 8 suggested complete, high hormonal dependence, whereas a score of 0 suggested there was no reaction. Our samples were negative.

The Ki67 index was determined by analysing and counting positive nuclei on 10 visible fields, at magnification $\times 40$. The index was expressed as a percentage, as the ratio of positive tumor cells in relation to negative, unstained cells.

\section{Morphometric analysis}

The morphometric analysis was performed in the software package "ImageJ" version 1.52a (public domain software, Wayne Rasband, National Institutes of Health, Bethesda, Maryland, USA). Color microphotographs were obtained using a high-resolution digital camera (Nikon, DS-Fi1, Tokyo, Japan) connected to the microscope (Nikon, ECLIPSE 50i, Tokyo, Japan). After that, the image was transferred to a compatible computer and nuclear parameters were analysed using the pack-age. The 8-bit image was manually processed, after calibration, using a computer mouse. 100 randomly selected tumor-cell nuclei of non-overlapping cells were analysed at magnification $\times 40$. The following parameters were analysed: Area, Perimeter, Feret diameter, all related to nuclear size, and Integrated Optical Density (IOD).

\section{Statistical Data Processing}

Continuous parameters were represented by mean values, standard deviations (SD) and medians. The normality of the distribution of continuous variables was determined using the Shapiro-Wilk test. Since the preconditions for using the analysis of variance (ANOVA) were not met, a comparison of the values of continuous variables between all groups was done individually using the Student's ttest of independent samples for normal distributions and the Mann-Whitney test for continuous parameters whose distributions deviated from normal.

\section{Results}

The study was conducted on samples of 64 carcinomas, and the histological presentation of triple-negative carcinomas is shown in Figure 1. 

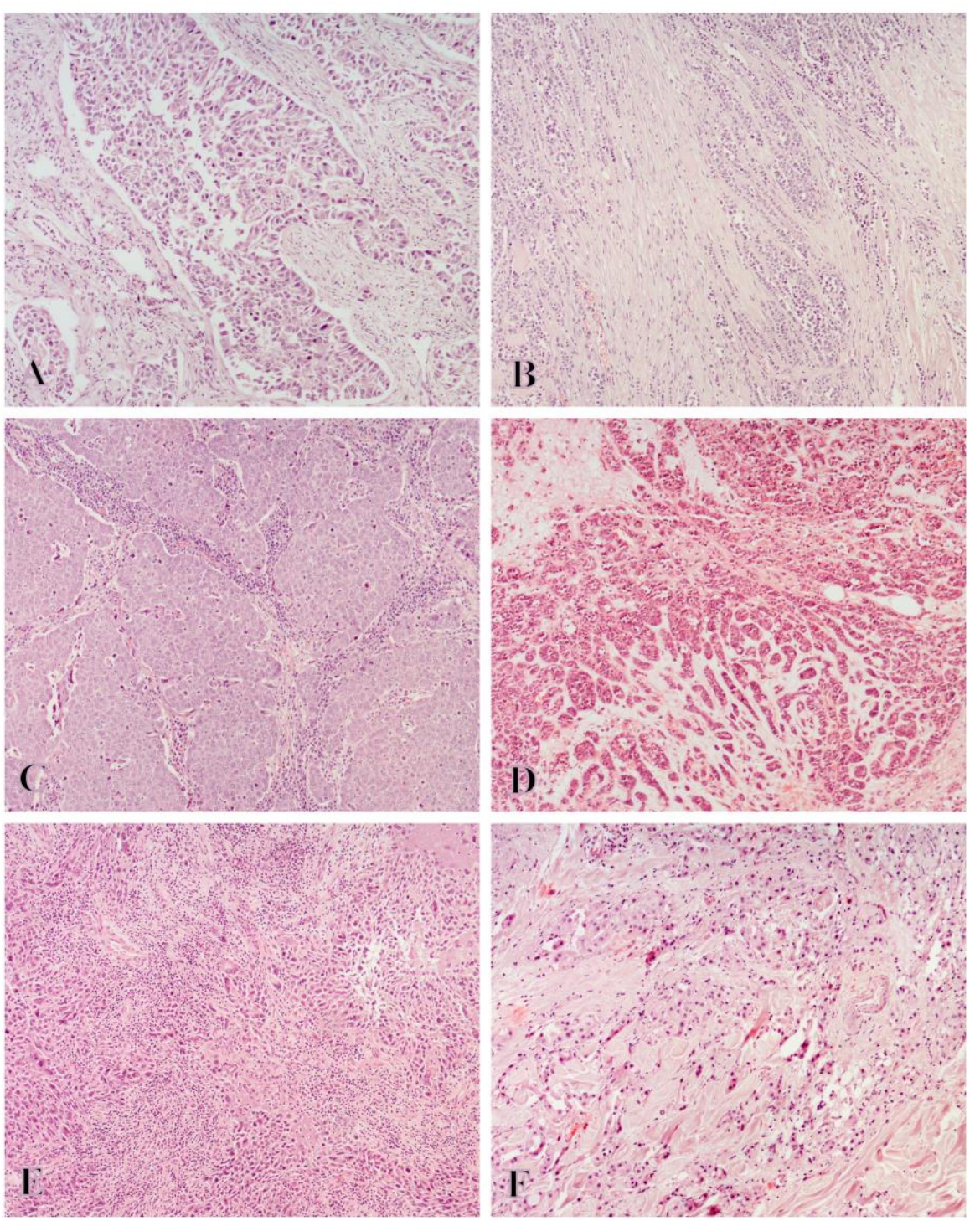

Figure 1. Six subtypes of triple-negative breast carcinoma (H\&E; magnification X200);

$$
\begin{aligned}
& \text { A - Ductal carcinoma (NST); } \\
& \text { B - Lobular carcinoma; } \\
& \text { C - Medullary-like carcinoma; } \\
& \text { D - Adenoid cystic carcinoma; } \\
& \text { E - Metaplastic carcinoma; } \\
& \text { F - Apocrine carcinoma. }
\end{aligned}
$$

The highest value of the parameter for nuclear size (Area) was reported in medullary-like carcinoma, statistically significantly higher than in lobular carcinoma $(p<0.01)$ and ductulolobular carcinoma $(p<0.05)$. In ductulolobular carcinoma, Area was also statistically significantly higher than in lobular carcinoma $(p<0.05)$ (Table 1$)$.

The highest value of Perimeter was also reported in medullary-like carcinoma, statistically significantly higher than in lobular carcinoma ( $\mathrm{p}<$ $0.01)$ and ductulolobular carcinoma $(p<0.01)$. Perimeter in ductulolobular carcinoma was also statistically significantly higher compared to metaplastic carcinoma $(p<0.05)($ Table 2$)$.
Furthermore, the highest values of Feret diameter were also reported in medullary carcinoma. They were statistically significantly higher compared to the values in lobular carcinoma and metaplastic carcinoma individually $(p<0.01)$ (Table 3$)$.

If we exclude apocrine carcinoma, which was present only in two cases, the next in value is ductal carcinoma NST, which has high standard deviation, followed by medullary carcinoma with low standard deviation and a value of integrated optical density statistically significantly higher than that of lobular carcinoma $(p<0.05)$ (Table 4$)$. 
Table 1. Nuclear size (Area) values by carcinoma type

\begin{tabular}{lcc}
\hline \hline Ductal carcinoma NST & $99.21 \pm 43.66$ & $(95.32)$ \\
Lobular carcinoma & $49.67 \pm 14.56$ & $(48.41)$ \\
Ductulolobular carcinoma & $95.40 \pm 16.67$ & $(95.40)$ \\
Medullary-like carcinoma & $98.05 \pm 5.87$ & $(97.95)$ \\
Adenoid cystic carcinoma & $68.84 \pm$ &. \\
Metaplastic carcinoma & $65.74 \pm 10.41$ & $(65.74)$ \\
Apocrine carcinoma & $84.23 \pm$. &.
\end{tabular}

Data are shown as mean \pm SD (Me)

$* \mathrm{p}<0.05, * * \mathrm{p}<0.01$, b - vs Carcinoma lobulare, c - vs Carcinoma ductulolobulare

Table 2. Nuclear perimeter values by carcinoma type

\begin{tabular}{||lccl||}
\hline Ductal carcinoma NST & $36.17 \pm 7.97$ & $(36.14)$ & \\
Lobular carcinoma & $26.36 \pm 3.59$ & $(26.28)$ & \\
Ductulolobular carcinoma & $36.21 \pm 3.13$ & $(36.21)$ & \\
Medullary-like carcinoma & $36.84 \pm 1.24$ & $(37.05)$ & b** \\
Adenoid cystic carcinoma & $30.62 \pm$. &. & \\
Metaplastic carcinoma & $30.31 \pm 2.07$ & (30.31) & f* \\
Apocrine carcinoma & $34.17 \pm$. & & \\
\hline
\end{tabular}

Data are shown as mean \pm SD (Me)

$* \mathrm{p}<0.05, * * \mathrm{p}<0.01, \mathrm{~b}$ - vs Carcinoma lobulare, $\mathrm{f}$ - vs Carcinoma ductulolobulare

Table 3. Feret diameter values by carcinoma type

\begin{tabular}{||lcc||}
\hline Ductal carcinoma NST & $13.16 \pm 2.90$ & $(12.92)$ \\
Lobular carcinoma & $9.60 \pm 1.36$ & $(12.97)$ \\
Ductalolobular carcinoma & $12.90 \pm 0.88$ & $(12.90)$ \\
Medullary-like carcinoma & $13.50 \pm 0.33$ & $(13.52) \quad$ bf** \\
Adenoid cystic carcinoma & $11.10 \pm$. & \\
Metaplastic carcinoma & $11.19 \pm 0.42$ & $(11.19)$ \\
Apocrine carcinoma & $12.62 \pm$. & \\
\hline
\end{tabular}

Data are shown as mean \pm SD (Me)

$* \mathrm{p}<0.05, * * \mathrm{p}<0.01, \mathrm{~b}$ - vs Carcinoma lobulare, $\mathrm{f}$ - vs Carcinoma metaplasticum

Table 4. Integrated optical density values by carcinoma type

\begin{tabular}{||lcc||}
\hline Ductal carcinoma NST & $34.46 \pm 12.90$ & $(32.65)$ \\
Lobular carcinoma & $18.93 \pm 5.77$ & $(16.48)$ \\
Ductalolobular carcinoma & $30.83 \pm 3.46$ & $(30.83)$ \\
Medullary-like carcinoma & $32.43 \pm 2.72$ & $(32.38) \quad$ b* $^{*}$ \\
Adenoid cystic carcinoma & $25.76 \pm$. &. \\
Metaplastic carcinoma & $25.70 \pm 2.07$ & $(25.70)$ \\
Apocrine carcinoma & $32.90 \pm$. &. \\
\hline
\end{tabular}

Data are shown as mean \pm SD (Me)

$* p<0.05, b-$ vs Carcinoma lobulare 
The highest value of the proliferative Ki67 index was found in metaplastic carcinoma and it was statistically significantly higher than the ones in lobular carcinoma $(p<0.05)$ and ductulolobular carcinoma $(p<0.01)$ (Table 5).

The highest value of the parameter for tumor size was recorded in ductulolobular carcinoma. However, due to the use of different statistical tests conditioned by the normality of distribution, only the value in ductulolobular carcinoma was found to be statistically significantly higher than that in metaplastic carcinoma $(p<0.05)$ (Table 6).

We excluded apocrine and adenoid cystic carcinoma, which were present only in two cases each, and therefore could not be compared to other carcinomas.

Table 5. Proliferative Ki67 index values by carcinoma type

\begin{tabular}{|c|c|c|c|}
\hline Ductal carcinoma NST & $48.00 \pm 11.92$ & $(48.50)$ & \\
\hline Lobular carcinoma & $44.00 \pm 3.61$ & $(45.00)$ & \\
\hline Ductalolobular carcinoma & $50.00 \pm 2.83$ & $(50.00)$ & \\
\hline Medullary-like carcinoma & $45.33 \pm 9.50$ & $(45.00)$ & \\
\hline Adenoid cystic carcinoma & $40.00 \pm$. & . & \\
\hline Metaplastic carcinoma & $51.50 \pm 2.12$ & $(51.50)$ & $\mathrm{b}^{* *} \mathrm{c}^{*}$ \\
\hline Apocrine carcinoma & $44.00 \pm$. & . & \\
\hline
\end{tabular}

Data are shown as mean \pm SD (Me)

* $\mathrm{p}<0.05$, b - vs Carcinoma lobulare, c - vs Carcinoma ductulolobulare

Table 6. Tumor size (pT) by carcinoma type

\begin{tabular}{||lcc||}
\hline \hline Ductal carcinoma NST & $2.40 \pm 1.05$ & $(2.00)$ \\
Lobular carcinoma & $3.00 \pm 1.00$ & $(3.00)$ \\
Ductalolobular carcinoma & $3.00 \pm 1.41$ & $(3.00)$ \\
Medullary-like carcinoma & $2.33 \pm 0.58$ & $(2.00)$ \\
Adenoid cystic carcinoma & $2.00 \pm$. & \\
Metaplastic carcinoma & $1.00 \pm$ & \\
Apocrine carcinoma & $4.00 \pm$. & \\
\hline Data are given as mean \pm SD (Me) & & \\
$* \mathrm{p}<0.05$, e - vs Carcinoma metaplasticum &
\end{tabular}

\section{Discussion}

Triple-negative breast cancers denote malignant epithelial tumors showing complete hormonal independence with negative HER2 expression (0, $1+)$. They were first defined in 2005 and represent $10-15 \%$ of all diagnosed carcinomas $(20,21)$. About $75 \%$ of triple-negative cancers express basal markers CK 5/6, CK 14, CK 17, vimentin, cadherin, calponin, S100, p63 $(22,23)$. Those tumors that are not characterized by the presence of basal antigens but belong to the triple-negative carcinoma subtype generally have better prognosis. Such cases were found in the metaplastic carcinoma group and the adenoid cystic breast carcinoma group. There are numerous features of triple-negative breast cancers that are not found in any other type or subtype. Histologically, in most cases these are high-grade tumors, showing fields of central necrosis, lympho- cytic infiltration, and fibrosis. In this type of tumors, there is often a discrepancy between the tumor size and the presence of metastases, either regional or distant, where even the smallest tumors were detected at stages when regional lymph nodal involvement was already present. In comparison to other types, more frequent metastases occurred at sites atypical for breast cancer such as visceral organs and soft tissues, unlike luminal tumors that most often metastasize to bone tissue, and brain metastases are identified as one of the most common. Carcinomas that occur more frequently in younger, premenopausal women are very often associated with BRCA1 and BRCA2 mutations, overweight women, and African-American women (24). These tumors are chemosensitive, therefore, chemotherapy is an optional method. Compared to other types, a relapse between 1 and 3 years after the diagnosis is much more common, thus the five-year 
survival rate for these carcinomas is very low. Therefore, these tumors are most often poorly differentiated with a high degree of proliferation and a very high metastatic potential (25).

Recent studies have been based on the detection and identification of genetic mutations we encounter in these highly aggressive carcinomas. Lehmann et al. isolated six subtypes of triple-negative breast cancer: basal-like 1 and basal-like 2 (BL1 and BL2), immunomodulatory (IM), mesenchymal, mesenchymal stem-like (MSL) and luminal androgen-like subtype (LAR) (17). The BL1 subtype includes the mutation of genes responsible for the cell cycle and reparation of DNA molecules, whereas the $\mathrm{BL} 2$ is characterized by the increased expression of epidermal growth factors. The IM subtype includes genes responsible for the regulation of immune processes, whereas mesenchymal and MSL types include genes responsible for cellular motility and differentiation. The LAR subtype is characterized by an expressed androgen receptor. In the BL1 and BL2 subtypes, mutations of BRCA1 and BRCA2 genes are much more common than in other subtypes (26). After thorough analyses and convincing evidence obtained by examining contributions of immune and mesenchymal cells, Lehmann et al. Revised the classification into 4 subtypes - BL1, BL2, mesenchymal subtype and LAR, and proposed additional testing to confirm with confidence the IM and MSL subtypes as such (27). Burstein et al. classified triple-negative carcinoma into LAR, mesenchymal, basal-like immunosuppressed and basal-like immune activated (28).

Changes in the appearance, structure, and size of the nucleus are some of the basic characteristics of a neoplastic cell (29). Our study was based on this from the start: to examine the morphometric parameters in different types of invasive breast cancers. In everyday clinical practice, a pathologist encounters a challenge, and sometimes a problem in determining the type of tumor, given that they are dealing with a polymorphic histological image. Certain studies have addressed the morphometric analysis and high-lighted the importance and applicability in the diagnosis of breast cancer (30-32). The most commonly analysed morphometric parameter is nuclear size (Area). Statistically significant differences in the medullary carcinoma group were obtained for morphometric parameters related to nuclear size. It was also observed that a statistically significant difference was present in the ductulolobular carcinoma group with respect to lobular carcinoma. Having analysed nuclear perimeter, a significant difference between ductulolobular carcinomas and metaplastic carcinoma was observed. The obtained results are considered to be of great use in everyday work, in the differentiation of different types of carcinomas. The integrated optical density was the highest in the ductal carcinoma group, but due to high standard deviation there were no statistically significant differences. A statistically significant dif-ference for this morphometric parameter was observed in the group of medullary carcinomas compared to the group of lobular carcinomas. In addition, these morphometric parameters have prognostic significance. In their study, Abdalla et al. specifically highlighted the size of the nucleus in tumor cells. This study suggested nuclear size of $71 \mu^{2}$ a criterion for the classification of tumors into two groups. All tumors with values less than the above can be classified in the group of carcinomas with better prognosis and a longer survival interval. In contrast, the group of tumors whose nuclear size is larger than the criterion above are considered carcinomas with worse prognosis $(30,33)$.

Metaplastic carcinoma showed the highest proliferative Ki67 activity.

\section{Conclusion}

A myriad of similar studies have attempted to identify a specific marker of these carcinomas, which is still a challenge due to their high aggressiveness. These are high-grade tumors with a broad spectrum of polymorphisms, quite often with an overlapping morphological presentation, therefore, additional analyses are required to set adequate diagnosis, as well as further therapeutic procedures. Using current knowledge, the therapy is based on surgical techniques, radiation and chemotherapy, or combinations of both. Regular mammographic examinations are today the most significant measure in preventing not only this type but all types of carcinomas, as well as constant education of women regarding self-examinations and numerous risk factors.

\section{Acknowledgment}

We would like to thank for the project funded by the Ministry of Education, Science and Technological Development of the Republic of Serbia "Virtual Human Osteoarticular System and its Application in Preclinical and Clinical Practice" (No. 41017), as well as for the internal project of the Faculty of Medicine in Niš - "Tumor-infiltrating Lymphocytes (TIL) as a Predictive and Prognostic Parameter after Neoadjuvant Therapy in Two Subtypes of Breast Cancer - Triple Negative and HER2 Positive" (No. 9). 


\section{References}

1. Boyle P. The globalisation of cancer. Lancet 2006; 368:629-30. [CrossRef] [PubMed]

2. Farhadian $M$, Mahjub $H$, Poorolajal J, Moghimbeigi $A$, Mansoorizadeh M. Predicting 5-year survival status of patients with breast cancer based on supervised wavelet method. Osong Public Health Res Perspect 2014;5(6):324-32. [CrossRef] [PubMed]

3. Kalogeraki A, Tamiolakis D, Kozoni V, Tzardi M, Panayiotides J, Melissas J et al. Nuclear grading in invasive ductal breast carcinomas. Cancer Detect Prev 2000;24:224-7. [PubMed]

4. Rosai J. Rosai and Ackerman's Surgical Pathology. Philadelphia (PA): Elsevier; 2004 pp. 1764-840.

5. Edge SB, Byrd DR, Compton CC, Fritz AG, Greene FG, Trotti A. AJCC Cancer Staging Manual. New York (NY): Springer; 2010

6. Giuliano AE, Connolly JL, Edge SB, Mittendorf EA, Rugo HS, Solin $D$ et al. Breast Cancer - Major changes in the American Joint Committee on Cancer eighth edition cancer staging manual. CA Cancer J Clin 2017;67:290-303. [CrossRef] [PubMed]

7. Fragomeni SM, Sciallis A, Jeruss JS. Molecular Subtypes and Local-Regional Control of Breast Cancer. Surg Oncol Clin N Am 2018;27(1):95-120. [CrossRef] [PubMed]

8. Freedman GM, Fowble BL. Local recurrence after mastectomy or breast-conserving surgery and radiation. Oncology (Williston Park) 2000;14(11):1561-81. [PubMed]

9. Obedian E, Haffty BG. Negative margin status improves local control in conservatively managed breast cancer patients. Cancer J Sci Am 2000; 6(1): 28-33. [PubMed]

10. Fisher B, Anderson S, Redmond CK, Wolmark N, Wickerham DL, Cronin WM. Reanalysis and results after 12 years of follow-up in a randomized clinical trial comparing total mastectomy with lumpectomy with or without irradiation in the treatment of breast cancer. N Engl J Med 1995; 333(22):1456-61. [CrossRef] [PubMed]

11. Web MD. Types of breast cancer: ER positive, HER2 positive, and triple negative. 2015. Available from: URL: http://www.webmd.com/breast-cancer/breastcancer-types-er-positive-her2-positive. (Accessed 27 Feb 2018).

12. Slamon DJ, Clark GM, Wong SG, Levin WJ, Ullrich A, McGuire WL. Human breast cancer: correlation of relapse and survival with amplification of Her-2/neu oncogene. Science 1987;235(4785):177-82. [CrossRef] [PubMed]

13. Wolff AC, Hammond ME, Schwartz JN, Hagerty KL, Allred DC, Cote RJ, et al. American Society of Clinical Oncology/College of American Pathologists guideline recommendations for human epidermal growth factor receptor 2 testing in breast cancer. Arch Pathol Lab Med 2007;131(1):18-43. [CrossRef] [PubMed]

14. Harvey JM, Clark GM, Osborne CK, Allred DC. Estrogen receptor status by immunohistochemistry is superior to the ligand-binding assay for predicting response to adjuvant endocrine therapy in breast cancer. J Clin Oncol 1999;17(5):1474-81. [CrossRef] [PubMed]

15. Schiff R, Osborn CK, F S. Clinical Aspects of Estrogen and Progesterone Receptors 2012.

16. Trihia H, Murray S, Price K, Gelber RD, Golouh R, Goldhirsch A, et al. Ki-67 expression in breast carcinoma: its association with grading systems, clinical parameters, and other prognostic factors-a surrogate marker? Cancer 2003;97(5):1321-31. [CrossRef] [PubMed]

17. Lehmann BD, Bauer JA, Chen $X$, Sanders $M E$, Chakravarthy $A B$, Shyr $Y$, et al. Identification of human triple-negative breast cancer subtypes and preclinical models for selection of targeted therapies. J Clin Invest 2011;121:2750-67. [CrossRef] [PubMed]

18. Goldhirsch A, Wood WC, Coates AS, Gelber RD, Thurlimann B, Senn HJ. Strategies for subtypes-dealing with the diversity of breast cancer: highlights of the St. Gallen International Expert Consensus on the Primary Therapy of Early Breast Cancer 2011. Ann Oncol 2011;22:1736-47. [CrossRef] [PubMed]

19. Herschkowitz JI, Simin K, Weigman VJ, Mikaelian I, Usary J, Hu Z, et al. Identification of conserved gene expression features between murine mammary carcinoma models and human breast tumors. Genome Biol 2007;8:R76. [CrossRef] [PubMed]

20. Brenton JD, Carey LA, Ahmed AA, Caldas C. Molecular classification and molecular forecasting of breast cancer: ready for clinical application? J Clin Oncol 2005;23:7350-60. [CrossRef] [PubMed]

21. Cleator S, Heller W, Coombes RC. Triple-negative breast cancer: therapeutic options. Lancet Oncol 2007;8:235-44. [CrossRef] [PubMed]

22. Bertucci F, Finetti P, Cervera N, Esterni B, Hermitte F, Viens $P$ et al. How basal are triple-negative breast cancers? Int J Cancer 2008;123:236-40. [CrossRef] [PubMed]

23. Bidard FC, Conforti R, Boulet T, Michiels S, Delaloge S, André $F$. Does triple-negative phenotype accurately identify basal-like tumour? An immunohistochemical analysis based on 143 'triple-negative' breast cancers. Ann Oncol 2007; 18:1285-6. [CrossRef] [PubMed]

24. Dent R, Trudeau M, Pritchard KI, Hanna WM, Kahn HK, Sawka CA et al. Triple-negative breast cancer: clinical features and patterns of recurrence. Clin Cancer Res 2007;13:4429-34. [CrossRef] [PubMed]

25. Onitilo AA, Engel JM, Greenlee RT, Mukesh BN. Breast cancer subtypes based on ER/PR and Her2 expression: comparison of clinicopathologic features and survival. Clin Med Res 2009;7(1-2):4-13. [CrossRef] [PubMed]

26. Perou CM, Sørlie T, Eisen MB, van de Rijn M, Jeffrey SS, Rees CA et al. Molecular portraits of human breast tumours. Nature 2000;406:747-52. [CrossRef] [PubMed]

27. Lehmann BD, Jovanović B, Chen X, Estrada MV, Johnson KN, Shyr $Y$ et al. Refinement of triplenegative breast cancer molecular subtypes: implications for neoadjuvant chemotherapy selection. PLoS One 2016; 11: e0157368. [CrossRef] [PubMed]

28. Burstein MD, Tsimelzon A, Poage GM, Covington KR, Contreras A, Fuqua SA, et al. Comprehensive genomic analysis identifies novel subtypes and targets of triplenegative breast cancer. Clin Cancer Res 2015;21: 1688-98. [CrossRef] [PubMed]

29. Pienta KJ, Coffey DS. Correlation of nuclear morphometry with progression of breast cancer. Cancer 1991;68:2012-16. [CrossRef] [PubMed]

30. Moroz K, Lipscomb J, Vial LJ Jr, Dhurandhar N. Cytologic nuclear grade of malignant breast aspirates as a predictor of histologic grade: Light microscopy and image analysis characteristics. Acta Cytol 1997; 41:1107-11. [CrossRef] [PubMed] 
31. Abdalla F, Boder J, Markus R, Hashmi H, Buhmeida A, Collan $\mathrm{Y}$. Correlation of nuclear morphometry of breast cancer in histological sections with clinicopathological features and prognosis. Anticancer Res 2009;29: 1771-6. [PubMed]

32. Aaltomaa S, Lipponen $P$, Eskelinen M, Kosma VM, Marin S, Alhava $E$, et al. Tumor size, nuclear morphometry, mitotic indices as prognostic factors in axillary-lymph-node-positive breast cancer. Eur Surg Res 1992;24:160-8. [CrossRef] [PubMed]

33. Giardina C, Renzulli G, Serio G, Caniglia DM, Lettini T, Ferri $C$, et al. Nuclear morphometry in node-negative breast carcinoma. Anal Quant Cytol Histol 1996;18: 374-82. [PubMed]

\title{
PREDIKTIVNI ZNAČAJ MORFOMETRIJSKE ANALIZE TRIPL NEGATIVNOG KARCINOMA DOJKE
}

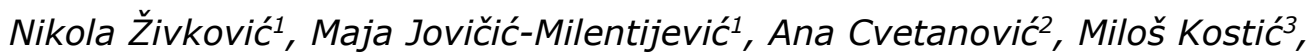 \\ Miodrag Đorđević ${ }^{4}$, Dane Krtinić 5
}

${ }^{1}$ Univerzitet u Nišu, Medicinski fakultet, Katedra za patologiju, Niš, Srbija
${ }^{2}$ Univerzitet u Nišu, Medicinski fakultet, Katedra za onkologiju, Niš, Srbija
${ }^{3}$ Univerzitet u Nišu, Medicinski fakultet, Predmet imunologija, Niš, Srbija
${ }^{4}$ Univerzitet u Nišu, Medicinski fakultet, Katedra za hirurgiju, Niš, Srbija
${ }^{5}$ Univerzitet u Nišu, Medicinski fakultet, Katedra za farmakologiju sa toksikologijom, Niš, Srbija

Kontakt: Nikola Živković

Bulevar dr Zorana Đinđića 81, 18000 Niš, Srbija

E-mail: nikola.zivkovic@medfak.ni.ac.rs

Tripl negativni karcinomi dojke predstavljaju maligne epitelne tumore koji pokazuju kompletnu hormonsku nezavisnost od negativne HER2 ekspresije. Histološki, u najvećem broju slučajeva, reč je o tumorima visokog gradusa, koji pokazuju polja centralne nekroze, limfocitnu infiltraciju i fibrozu. Cilj istaživanja zasniva se na ispitivanju morfometrijskih parametara, koji se odnose na veličinu jedra u zavisnosti od tipa karcinoma, kao i na proliferaciju tumora. Celokupno istraživanje sprovedeno je u Centru za patologiju i patološku anatomiju Kliničkog centra Niš. Analizirano je 64 biopsijska uzorka trostruko negativnih karcinoma dojke, i to 40 duktalnih, 6 lobularnih, 6 medularnih, 4 duktulolobularna, 4 metaplastična, 2 adenoidno cistična i 2 apokrina karcinoma. Morfometrijska analiza vršena je u softverskom paketu "ImageJ" verzija 1.52a. Statisitička analiza podataka rađena je u programskom paketu SPSS 15.0. Poređenjem vrednosti ispitivanih morfometrijskih parametara ustanovljene su statistički značajno više vrednosti parametara za površinu, obim i Feretov dijametar uzoraka grupe medularnih karcinoma, kao i parametra za Integrisanu optičku gustinu uzoraka iste grupe. Integrisana optička gustina bila je izrazito visoka i kod uzoraka u grupi duktalnih karcinoma, ali bez statistički značajne razlike zbog visoke standardne devijacije. Najveću proliferativnu aktivnost imao je metaplastični karcinom. Brojna istraživanja, slična ovom, pokušavaju da identifikuju specifičan marker ovih karcinoma, koji zbog velike agresivnosti i danas predstavlja izazov. Reč je o tumorima širokog spektra polimorfizma, visokog gradusa, sa veoma često preklapajućom morfološkom prezentacijom, pa su dodatne analize neophodne u cilju postavljanja adekvatne dijagnoze.

Acta Medica Medianae 2020;59(2):38-46.

Ključne reči: tripl negativni karcinom dojke, imunohistohemija, morfometrija 